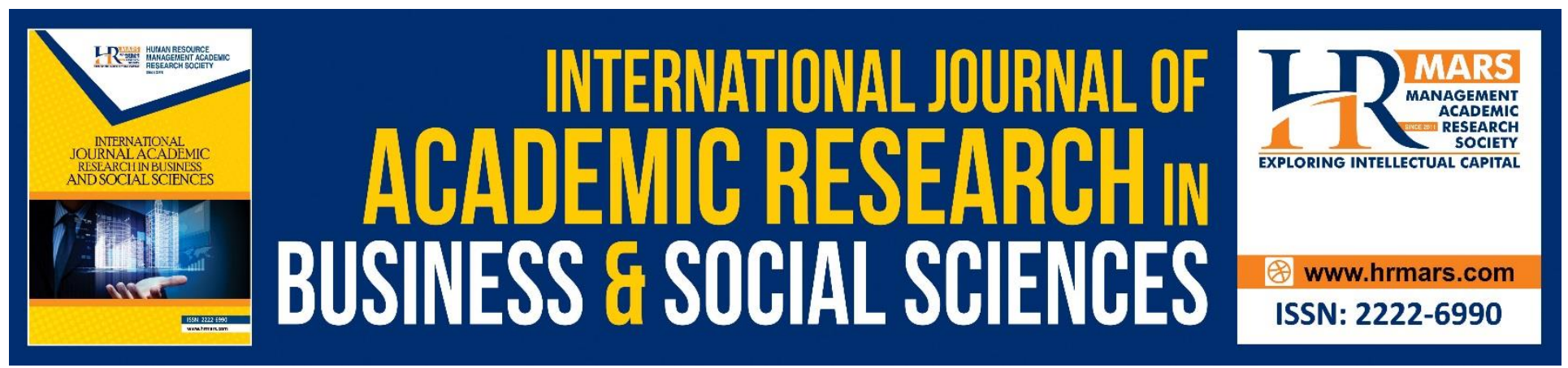

\title{
The Determinant of Online Shopping Intention in Jordan: A Review and Suggestions for Future Research
}

Malek Ahmad Salem Alsoud, Ismail bin Lebai Othman

To Link this Article: http://dx.doi.org/10.6007/IJARBSS/v8-i8/4507

DOI: $\quad 10.6007 /$ IJARBSS/v8-i8/4507

Received: 07 July 2018, Revised: 06 August 2018, Accepted: 29 August 2018

Published Online: 07 September 2018

In-Text Citation: (Alsoud \& Othman, 2018)

To Cite this Article: Alsoud, M. A. S., \& Othman, I. bin L. (2018). The Determinant of Online Shopping Intention in Jordan: A Review and Suggestions for Future Research. International Journal of Academic Research in Business and Social Sciences, 8(8), 441-457.

Copyright: (c) 2018 The Author(s)

Published by Human Resource Management Academic Research Society (www.hrmars.com)

This article is published under the Creative Commons Attribution (CC BY 4.0) license. Anyone may reproduce, distribute, translate and create derivative works of this article (for both commercial and non-commercial purposes), subject to full attribution to the original publication and authors. The full terms of this license may be seen

at: http://creativecommons.org/licences/by/4.0/legalcode

Vol. 8, No. 8, August 2018, Pg. 441 - 457

http://hrmars.com/index.php/pages/detail/IJARBSS

JOURNAL HOMEPAGE

Full Terms \& Conditions of access and use can be found at http://hrmars.com/index.php/pages/detail/publication-ethics 


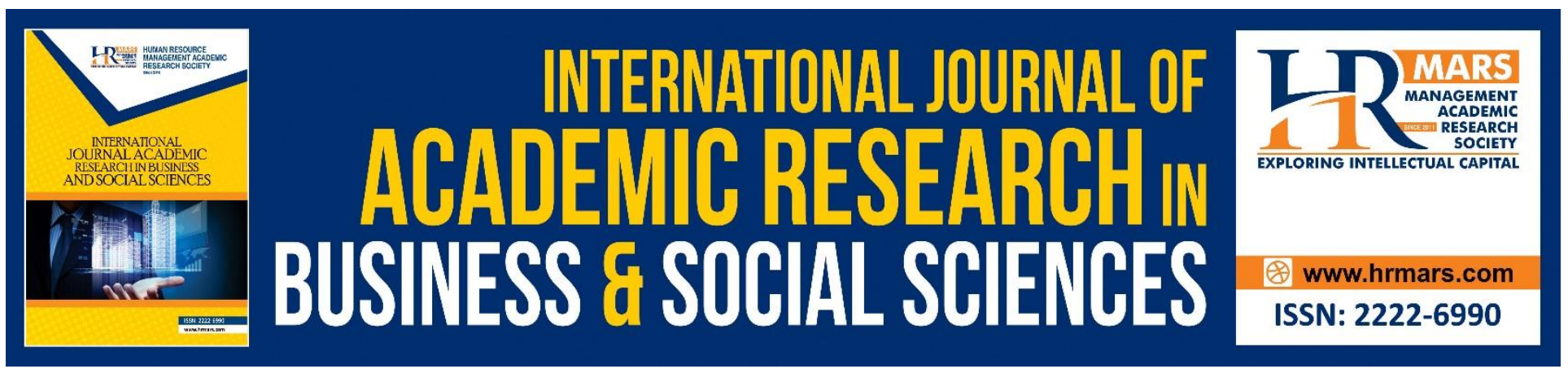

\title{
The Determinant of Online Shopping Intention in Jordan: A Review and Suggestions for Future Research
}

\author{
Malek Ahmad Salem Alsoud \\ PhD Scholar, College of Business, UUM Sintok, Malaysia \\ Email: alsoud.malik@gmail.com
}

\author{
Ismail bin Lebai Othman, Ph.D. \\ Associate Professor, College of Business, UUM Sintok, Malaysia \\ Email: i.othman@uum.edu.my
}

\begin{abstract}
In recent years, the online business environment has become a very dynamic and highly competitive due to the globalization and massive developments in this sector. Online shopping has faced many challenges to deal with business challenges and to attain consumer intention. Online retailer needs to be a focus on the critical variables which concern consumer to avoid online shopping and to develop a robust e-commerce website to enhance customer trust and get consumer intention. Online shopping in Jordan faces many challenges, Jordanian customers are cash oriented, and the usage of online shopping is decreasing year by year. Drawing from the technology acceptance model (TAM), this study aims to understand why Jordanian distance themselves from online shopping and to propose the novel conceptual model standing on factors that may affect consumer intention to shop online such as, website credibility, website quality, security protection, after-sale service on online shopping intention. The study also highlighted the important role of perceived trust and electronicword of mouth (e-WOM) as a moderator in the relationship between these factors and online shopping intention. Based on the review of relevant literature, the proposed conceptual model would hopefully lead to helpful insights for the online retailer and future researchers.

Keywords: Online Shopping, Intention, Perceived Trust, E-wom, Website Credibility, Website Quality, Security Protection, After-Sale Service.

\section{Introduction}

In the current era of globalization, the online business environment is continuously changing, to deal with the market challenges; e-commerce retailer needs to evaluate a website to help in achieving the competitive advantage and enhanced consumer shopping intention. However, how consumer
\end{abstract}


INTERNATIONAL JOURNAL OF ACADEMIC RESEARCH IN BUSINESS AND SOCIAL SCIENCES

Vol. 8, No. 8, August 2018, E-ISSN: 2222-6990 @ 2018 HRMARS

intention achieved and what factors should be considered by the e-commerce retailer to develop their website in developing countries is still issue needs further investigated.

In the field of e-commerce business, online shopping intention has resulted to be one of the critical prospects for measuring individual behavior, and opinions (Flavián, Guinalíu, \& Torres, 2006). It is convenient to understand that when the user is happy with the service provided, they are more motivated towards to repurchase. Hence, higher service and consumer trust in e-commerce website can lead towards higher intention and loyalty (Anderson \& Sullivan, 1993; Flavián et al., 2006; Kim \& Kim, 2004). In this way, also outlines that user satisfaction is closely interrelated with positive experiences and intention to use e-commerce website (DeLone \& McLean, 2003). Therefore, online shopping retailer should be responsively taken into consideration the factors that affect customers intend to use the e-commerce website.

Furthermore, as the world continues to focus more on the Internet, businesses have found new entries on working upon online shopping. The main objective of getting closer to customers is to make better marketing arrangements. Statistica-Corporation (2015) has outlined that overall online shopping by using the internet reached 839.8 billion dollars in 2013 and was expected to accomplish 1.5 trillion dollars by 2018 . They also said that North America has the best online shopping market which could make offers of around 126 billion U.S. dollars. It is trailed by Europe, mainly, the United Kingdom along making 107 billion euros' sale through online platforms. Cushman and Wakefield, (2013) demonstrated that most countries in Europe, for instance, United Kingdom, Germany, France, Netherlands manage the overall online retail feature. These countries are driving concerning the web establishment fusing market measure and in mishandling market openings. The Czech Republic ranks 29th in physical shopping spree 34th in online structure (Cushman \& Wakefield, 2013).

When we investigated the global economy, the importance of the online shopping significantly increased due to their rise to overall economy and usefulness. The online shopping retailer has shown the need to enhance their online website in order to gain consumer intention. Online shopping is an Internet application which spread speedily in all over the world, particularly in the developed country, but whose growth has been slower in developing countries, because of infrastructural, and consumer distrust (Nuseir \& Arora, 2010).

Notably, the online shopping in Jordan as a developing country in the middle east still facing many challenges of online shopping and e-commerce website (Nabot, Garaj, \& Balachandran, 2014). The internet penetration in Jordan was $88 \%$ (statista.com). Moreover, the Department of Statistics (2017) in Jordan reported that online shopping rate in Jordan is 4.8 percent. According to Al-Matarneh (2016), the growth of online shoppers decreased to $8 \%$ in $2015-2016$ comparative to $14 \%$ in 2011 2012. In the lieu, the question now is why Jordanian distance themselves from online shopping, whereas the internet penetration in Jordan is high compared to other Middle East countries?

Besides, The number of Jordanian complaints about fraud and web credibility during shopping online has been increased significantly (Istizada, 2016). The Jordanian Telecommunications Regulatory Commission (2013), reported that Jordanian government blocked around 300 fake and unauthorized websites. Internet users in Jordan face several cyber threats and are vulnerable to those attacks, as they do not adopt proper security systems. As reported by Arab Advisers Group (2011), 72.8 percent of Jordanian consumer believe that e-commerce website is not secure.

Despite the availability of e-commerce websites in Jordan, Ministry of Information and Communications Technology (2016) reported, that the payments were made between Jordanians and Jordanian companies online is very low compared to that occurs between Jordanian and foreign suppliers that do have adequate payment facilities at their disposal. Hasan and Morris (2017) 
reported many issues related to websites quality in Arab E-commerce websites, like: inaccurate information, unavailability products, long ordering process, unclear website content, unavailability of alternative methods of delivery, inappropriate font size and inconsistent language. For that, Ecommerce companies should take into consideration websites quality as an essential factor to enhance the online customer's intention as suggested by (Al-dweeri et al. 2017).

Therefore, in order to enhance the level of online shopping in Jordan, it is essential for the ecommerce retailer to develop the secure website that meets Jordanian customer needs and improve the trust between their website and customers. Moreover, researchers have Considering this philosophy; the current study aims to propose the conceptual model representing the impact of website credibility, website quality, security protection, after-sale service on online shopping intention. This study also highlighted the critical role of perceived trust and electronic-word of mouth (e-WOM) as a moderate's relationship between these factors and online shopping intention in Jordan. Moreover, the investigation of the proposed conceptual model will also enhance our understanding of the implementation of these factors at online shopping intention. Also, this study provides future empirical studies.

The next section reviews the technology acceptance model (TAM) related to the relationship between of website credibility, website quality, security protection, after-sale service on online shopping intention. Then, a review of the literature discussed and proposed the research propositions. Next, a proposed conceptual model presented. Followed by a methodology, discussion, conclusion, and implications.

\section{Underpinning Theory}

Technology acceptance model (TAM) provides a useful account of how the website credibility, website quality, security protection, after-sale service lead towards enhancing online shopping intention. This theory also underpinned the proposed conceptual model presented in the current study.

\section{Technology Acceptance Model (TAM)}

The theoretical research model using in our study based on the extended Technology Acceptance Model (TAM) of Davis et al., (1989). This theoretical research lens is parallel in spirit to Davis formulation of the Technology Acceptance Model (TAM). While the TAM model, as expanded by (Davis,1989) have been used widely in research in the industrialized world.

Substantial theoretical and empirical support has gathered in favor of the Technology Acceptance Model (Davis, 1989). Several studies have found that (TAM) consistently explains a significant proportion of the variance in intentions and behavior. Also, TAM compares favorably with other models such as Theory of Reasoned Action and Theory of Planned Behavior (Venkatesh, 1999). TAM theorizes that an individual's behavioral intention to use a system determines by two beliefs: usefulness, and ease of use (Venkatesh, Davis, \& College, 2000). Online shopping has essentially developed and is progressively getting to become distinctly prominent since its beginning nearly two decades ago. Accordingly, as the world continues to focus more on the Internet, businesses have found new entries on working upon online shopping.

According to TAM, two key beliefs of determining the intention to accept voluntarily and then use a new IT that received enormous attention are the perceived usefulness (PU) and the perceived ease of use (PEOU) of using the new IT (Chau et al., 2000; Lin and Lu, 2000). The TAM has proved useful as the prominent theory in IT studies (Straub et al., 1997; Chen et al., 2002). Empirical research has 
INTERNATIONAL JOURNAL OF ACADEMIC RESEARCH IN BUSINESS AND SOCIAL SCIENCES Vol. 8, No. 8, August 2018, E-ISSN: 2222-6990 @ 2018 HRMARS

shown the TAM to be a robust model for studying technology acceptance behaviour in a wide range of IT categories, including electronic commerce (Gefen \& Straub, 2000; Gefen, Karahanna, \& Straub, 2000) and in studies across countries (Straub et al 1997; Rose \& Straub, 1998). Mathieson, Peacock, and Chin (2001) extended the TAM to include perceived ease of use of a resource. However, their study identified one limitation for the TAM in the assumption that the usage is volitional, meaning there are no barriers to prevent individual usage.

While the TAM initially focuses on system usage in the online environment, the researcher has attempted to use TAM to understand website use (Moon \& Kim, 2001). Hence, intentions to use the Internet for online shopping could consider the major constructs of TAM: perceived usefulness and perceived ease of use. Both the PU and PEOU beliefs in the TAM model predict the attitudes of individuals towards using the computing system and influence the behavioral intention and actual use. Bruner and Kumar (2005) state that the main idea underlying the TAM model is that a person's behavioral intention to use the system determines by usefulness and ease of use. According to the TAM, perceived usefulness is influenced by perceived ease of use because the easier the system is to use, the more useful it can be (Venkatesh \& Davis, 2000). The model has recently been updated (Venkatesh \& Davis, 2000) with a number of antecedents of usefulness and ease of use, including subjective norms, experience, and output quality. One of the main goals of research in the field of Information Systems (IS) is to forecast the adoption and usage of IT, based on an understanding of the individual's acceptance of it and in particular, the consideration of usage (Melone, 1990; Davis, 1989). At the same time, researchers have made significant efforts to build theories that can be used to examine and predict the factors responsible for determining the acceptance of IT (Agarwal and Prasad, 1999). Within the TAM framework, the usefulness of the interactive media can be thought of as reflecting the more instrumental aspects of shopping, while enjoyment embodies the hedonic aspect of shopping. The TAM has gained considerable support, and its use in different fields of research has demonstrated its ability to explain behavior. Davis suggests that future technology acceptance research needs to address how other variables affect usefulness, ease of use, and user acceptance (Moon \& Kim, 2001).

While there are existing studies concentrated on online shopping around the world, many of these studies suggested that there is still a need for closer examination of the online shopping intention in specific countries, very much due to the fact of cultural differences and the prior imperfection of technology acceptance relationships of varying consumer markets (Bobbit \& Dabholkar, 2001; Goldsmith, 2002; Salisbury et al., 2001). Considering that online shopping is still at the early stage of development in Jordan, little is known about consumers' behaviour in adopting this new shopping channel and the factors which influence this behavior (Haque et al., 2006). This study aims to fill this gap by examining how consumers form their attitudes and make online shopping intentions. This study employs TAM as the underlying theoretical grounding for the research framework as it provides a valid basis for explaining and predicting consumers' intention towards online shopping behavior (Bobbit \& Dabholkar, 2001; Goldsmith, 2002; Grabner-Krauter \& Kaluscha, 2003; Haque et al., 2006; King \& He, 2006). The knowledge this study generates will contribute in two ways: regarding theory, this study provides an empirical understanding on the technology acceptance of Jordanian consumers towards online shopping; and regarding practice, this study presents strategic implications and directions for the development of online shopping in Jordan. 
INTERNATIONAL JOURNAL OF ACADEMIC RESEARCH IN BUSINESS AND SOCIAL SCIENCES

Vol. 8, No. 8, August 2018, E-ISSN: 2222-6990 @ 2018 HRMARS

\section{Literature Review and Research Propositions}

This section attempts to review the recent research into the relationship between website credibility, website quality, security protection, after-sale service lead towards enhancing online shopping intention. Moreover, standing on the literature review, the research propositions have established.

\section{Website credibility and online shopping intention}

The credibility of the website considered as one of the most important factors that contribute to enhancing the behavior and intention to online shoppers. (George, Mirsadikov, \& Mennecke, 2016; Toufaily, Souiden, \& Ladhari, 2013). Website credibility is generally characterized as the level of detail an assortment of data which are resolved amid the framework plan and advancement stage while the opportuneness, exactness, and consistent quality outcome (Toufaily et al., 2013). Moreover, scholars have empirically measured the association between credibility and consumer behavior. High credibility sources can positively impact on intention, whereas low credibility sources are less likely to contribute a behavioral intention (Hassan, Walsh, Shiu, Hastings, \& Harris, 2007).

Website Credibility, a term used to refer to this perception of the image, is a strong predictor of attitudinal and behavioral in an audience (McCroskey, 1971). Numerous studies conducted on the many aspects of source credibility: what factors comprise source credibility (Gotlieb \& Sarel, 1992; Ohanian, 1990), how to measure it (Gotlieb \& Sarel, 1992; Johnson \& Kaye, 2004; MacKenzie \& Lutz, 1989) and how it defined on the Internet (Kim, 2015). Source credibility closely linked to the concept of purchase intention, a strong predictor of purchasing behavior (Fishbein \& Azjen, 1975), and a major area of interest for marketing professionals and academics alike. Purchase intention research has focused on how credibility had been using as a measure in marketing (Dodds, Monroe, \& Grewal, 1991; Infosino, 1986), More recent research has looked at how shopping intention may be affected by attributes of online stores (Chen, Hsu, \& Lin, 2010).

In sum, website credibility offers noteworthy stimulus that influences individual intention being users about the value of the information systems and how they can potentially implement these prospects in different occupation settings (Saeed \& Abdinnour-Helm, 2008).there was an agreement in the previous studies concerning the importance of the effect of website credibility on the usage of the technology. Based on the existing empirical evidence, this study considers website credibility as an important determinant of the users to online shopping intention. Moreover, there is a need to consider the effect of website credibility towards the intention, to use technology in different cultural and organizational settings, especially in Jordanian context.

\section{Website Quality and Online Shopping Intention}

Typically, consumers may face difficulties while shopping the first time, as a consumer may take extra time to find and locate their desired products and extract information. If the web-based retailer fails to respond to this kind of consumers, then it would place a huge question mark on online selling in the future (Lee et al., 2011). The functionality of the website in association with providing information related to the products and goods, providing information related to guide for online shopping also helps customers to get engage in online shopping as claimed by Bai, Law, and Wen (2008) as cited by (Lee et al., 2011). Chen and Barnes (2007) found that quality of information and guidelines for online purchase increase trust and benevolence of consumers to shop online as attractive interface also helps to build trust through quality information provided by the retailer. Website design and the ability of a website to handle the customer through its navigation also helps the web-based retailer to attract customers (Tsai \& Yeh, 2010). 
INTERNATIONAL JOURNAL OF ACADEMIC RESEARCH IN BUSINESS AND SOCIAL SCIENCES

Vol. 8, No. 8, August 2018, E-ISSN: 2222-6990 @ 2018 HRMARS

Website quality considered an insistent concept in the internet world. Nowadays, online commercial companies cannot attract a wide range of customers without a proper website quality (Khalil, 2017). Website quality is considered the website's skills to allow users to achieve their purpose and willingness of users to visit the website to perform the same on an ongoing basis (Loiacono, Watson, \& Goodhue, 2002). Website quality affects the customers' intention to purchase via webstores (Bai et al., 2008).

Website quality is "the attributes of a website that contribute to its usefulness to consumers." Prior website quality research has shown numerous website quality dimensions, including information quality, ease-of-use, usability, (Aladwani \& Palvia, 2002; H. W. Kim, Xu, \& Koh, 2004; Lin, Chuang, Kao, \& Kung, 2005; Ranganathan \& Ganapathy, 2002; Vishwanath \& Barnett, 2005);A number of researchers examining the impact of website quality on user intention to shop online, they have found that website quality can impact in online shopping intention (Belanger, Hiller, \& Smith, 2002; Gregg \& Walczak, 2010; Mcknight, Cummings, \& Chervany, 2007; Pavlou, P. A., \& Gefen, 2004). Quality of website will directly influence website user's intentions (Hsu, Chang, \& Chen, 2012). Aldweeri et al. (2017) recommended extensive websites quality, to examine the handling of the eservice quality which would lead to an enhanced intention of online customers Website quality is perceived somewhat less important in Jordan (Debei, 2014; Masoud, 2013). Therefore, further studies are needed to forward generalizable results for the Jordanian economy. It is also essential in a way as often consumers are motivated to rate the website high due to its design, layout, and quality of information it provides (Al-maghrabi, Dennis, \& Vaux Halliday, 2011).

Moreover, most studies examining this relationship have conducted in the developed countries, and very limited has focused on the developing countries context. Thus the current study recommends examining this relationship in the context of a developing country like Jordan.

\section{Security Protection and Online Shopping Intention}

Security and protection play a critical role in the online environment. Moreover, it is a major area of interest within the field of individual behavior and online marketing. Generally, online security protection is an essential aspect of online shopping (Omar, Scheepers, \& Stockdale, 2011). According to Abbad et al. (2011), security and protection as one from among others address that needs a huge imperative for online business in Jordan. Associations in Jordan need to focus on trust keeping in mind the end goal to win on the web (Xu, 2013). For improving the level of customer trust in ecommerce, online shopping sites in Jordan need to concentrate on insurance, and security edges as critical drivers of diminishing saw perils from online purchaser's perspectives. In the light of the fact that security protection had comprehensively seen as the principal obstacles to the allocation of online shopping sites as a result of their large effect on trust and on forming inspiring demeanors toward online shopping later on.

Moreover, expressed that security of money related and individual information gave on the online shopping websites is a far-reaching concern (Horrigan, 2008). According to Lee, Chiu, and Liu (2011), online consumers were reluctant to shopping online principally on account of security issues. As most of the online shopping platforms ask consumers to provide necessary information, buyers are concerned about the possibility that that online retailer may abuse or may not regard the secrecy of the data. In the meantime, this dread is additionally combined with the past deceitful exercises happening in the online condition. Fundamentally, shoppers require protection. They need that the individual data they gave on the website will be shelter and secured. 
Regarding online shopping, security protection is extremely critical behavioral control considers encouraging online shopping conduct, what's more; the outcome demonstrated that exclusive and security in saw behavioral control build had decidedly connected with the goal of shopping on the web. (Gauzente, 2004; Lian \& Lin, 2008; Wang, Lin, \& Luarn, 2006; Zailani, Kheng, \& Fernando, 2008; Zhang \& Tang, 2006). Security and protection were also reported to be important determinants of online shopping (Kim et al., 2011; Llach et al., 2013; Wu \& Chang, 2005). In the contextual understanding handful of studies can be tracked which cannot be view as conclusive. In the same vein, studies (Altarifi, Al-hawary, \& Sakkal, 2015; Yaseen, Dingley, \& Adams, 2016) investigated found positive and significant aspects.

In sum, security and protection is an essential variable in online shopping intention, particularly in the internet user's context. Internet users do not like their credit card particulars, for example, to fall into the hands of the cybercriminals. Thus, it is this factor that has also led to the low usage of online shopping in Jordan. The above studies are also found to be fragmented and diverse. Instead of this, more extensive studies are required to explore the security and protection and how it influences online shopping intention of customers.

\section{After-Sale Service and Online Shopping Intention}

The major hurdle for online shopping is the unavailability of physical touch and product examination which has been one of the significant limitations of online shopping. People in Jordan are cash oriented and also afraid to use their credit cards to buy online (Ghazal, 2102). People are concerned about after-sale service, as they do not see the people or the physical items they buy. Another issue is receiving a different product from the products purchased online, as well as some consumers have doubts about the quality of items purchased. Those issues discourage Jordanian customers from a shop online (Yaseen et al., 2016). Consider after-sales service, and showing a real interest in solving countered problems and providing a quick response to a customer, and enhance the level of online shopping in Jordan (Al-dweeri,2017). In the relation, several studies have highlighted customer dissatisfaction regarding after- sales service in the process of online shopping (Chen, Yan, Fan, \& Gordon, 2015).

Furthermore, online shopping does not allow the customer to touch or experience products on sale. The customer decides the destiny of products with the plausible look and visual experience. Additionally, after-sale service, in the form of guarantee of product return and faulty product or information mentioned in the website does not match to products feature off after-sales service effect on the intention of online shopping (Al-Rawad, Al Khattab, Al-Shqairat, Krishan, \& Jarrar, 2015; Aldhmour \& Sarayrah, 2016)

After-sales services are the potential loss of after-sales service associated with product problems, commercial disputes, and service guarantee (Sinha \& Singh, 2015). The after-sales service stage incorporates customer administration, conveyance, and issue a determination. This stage ought to produce or acquire consumer loyalty by meeting different desires of customers and enhance customer intention. (Toufaily et al., 2013).

Several studies have highlighted customer dissatisfaction regarding after sales and service in the process of online shopping (Alireza, Fatemeh, \& Pegah, 2011; Chen, Yan, Fan, \& Gordon, 2015). These factors can increase the level of satisfaction for customers; either by lowering the expectations of the customer or by improving the understanding of customer services (Tang, \& McCullough, 2000). Numerous studies and researches conducted especially over the last ten years about after-sales 
INTERNATIONAL JOURNAL OF ACADEMIC RESEARCH IN BUSINESS AND SOCIAL SCIENCES

Vol. 8, No. 8, August 2018, E-ISSN: 2222-6990 @ 2018 HRMARS

services can be noted in this regard with the intention (Al-Rawad et al., 2015; Aldhmour \& Sarayrah, 2016).

Some authors suggest conducting a study examining after-sales services in the light of online shopping determinants (Al-dweeri, Obeidat, Al-dwiry, Alshurideh, and Alhorani, 2017). Moreover, they suggested in a way that after-sales service can dominantly influence relationships with customers (Amini, Darani, \& Afshani, 2012). In the light of a contextual understanding of Jordan past studies did not highlight the issues of after-sale service and studies has given less important factor in the online shopping aspect (Al-Rawad et al., 2015; Aldhmour \& Sarayrah, 2016). The scarcity of literature and required comprehensive and detailed inquiry to explore the after-sale services as the antecedents, predictors or determinants in the online shopping (Ahmed \& Sanatullah, 2011). Hence, further empirical attention is required to forward more generalizable results about after-sales service in the context of Jordan.

\section{Perceived Trust and Online Shopping Intention}

Perceived trust as a moderating variable defines as a variable that affects the direction and strength of the relationship between an independent variable and a dependent variable (Baron \& Kenny, 1986). The online shopping intention effects by several psychological factors; these factors effect on the decision-making process of online shopping customer (Kumar, 2010; Zakuan et al., 2012). The online shopping firms who ignore the trust is supposed to perform devalue. Some of the researchers claimed that trust is an essential aspect of customer who is willing to buy products from the online shopping. In some of the countries, trust is given the priority in the online shopping mechanism (Lee et al., 2011; Lu et al., 2011; Zhou, 2013). Hence the nature and dynamic of perceived trust serve as the source of online shopping activities. Thus, high in trust on website information, quality, credibility and security, and protection give benefits to the online shopping companies. According to (Ganguly et al., 2010) trust factors are given the confidence to the customer because they can get more benefits in the low risk of online shopping.

Previous studies have underlined the importance of trust as one of the key antecedent for to increase shopping intentions (David Gefen, 2003; Hassanein \& Head, 2007; Limbu, Wolf, \& Lunsford, 2012; Wang \& Emurian, 2005). Moreover, Thamizhvanan and Xavier (2013) found that trust strongly affects purchase intention among young consumers. Higher consumer online trust leads to higher online purchase intention. (M. Y. Chen \& Teng, 2013; Lan Ho \& Chen, 2014; Thamizhvanan \& Xavier, 2013; Ubaid Ur Rahman, Muhammad Rizwan, Muhammad Rizwan, 2013). According to Ganguly (2009) trust towards the website can be created by implementing website factors such as privacy and security, because customers give more importance to privacy and security and subsequently enhance purchase intention. Although there is a shortage of literature, it is possible that trust performs a moderating factor toward behavior intention in online shopping. From this reason, an attempt will be made to develop an extension of TAM with additional factors and determine if it can help to predict customers intention better, or not, by investigating the online shopping patterns of Academicstuff consumers in Jordan.

\section{Electronic Word of Mouth (e-WOM)}

The Internet makes it feasible for buyers to acquire electronic exchange from different customers (Hennig-Thurau, \& Walsh, 2003). E-WOM refer to "any positive or negative statement made by potential, actual, or former customers about a product or company, which is made available to a multitude of people and institutions via the Internet" (Hennig-Thurau, T., \& Walsh, 2003). Since the 
first appearance of e-WOM, prior researchers have demonstrated several consequences such as effectiveness, valence, an individual's response.

Many customers preferred reading suggestions given by experienced customers before buying certain types of products or services, especially those related to product information in general, experienced customers gave opinions found to significantly influence new customers' purchasing intention (Senecal \& Nantel, 2004). Throughout direct and continuous interacting with customers; marketers can drive customers to carry out more effective e-WOM behaviors from different platforms. (José-Cabezudo \& Camarero-Izquierdo, 2012; Strutton, Taylor, \& Thompson, 2011).

In response to the new phenomenon, academicians and practitioners have started to pay more attention to the new opportunity, and the potential impact of e-WOM on business performance. Many studies have conducted regarding e-WOM effectiveness in online shopping. For instance, Chen, Dhanasobhon, and Smith (2008) have examined the quality of online product message, and the reputation of the communicator influence books purchase decisions at Amazon.com, the study found that high rating and quality of online review have a substantial impact on purchase decision while the reputation of the sender has not. Likewise, Chevalier and Mayzlin (2006) investigated the impact of consumer online contribution reviews on sales of books at Amazon.com. They found that e-WOM has a causal effect on purchasing attitude at the Internet and websites

e-WOM has received extensive attention in the literature that explains the power of this message on the purchase decision, product and brand construct. Most of these studies found that positive eWOM associated with consumer's satisfaction and they are motivated to contribute their experience for several issues such as commitment and concern for others. Despite the vital role of product quality and price in determining the message direction either positive or negative, emotions also could induce consumers' in a positive e-WOM communication about products services and companies (White, 2010).

On the other hand, Literature has recognized negative e-WOM as a result of bad consumption experience and dissatisfaction. According, Richins (1983) indicated that the potential response of unfavorable experience includes "switching brand, making a complaint to the seller, and telling others about the unsatisfactory product or retailer." People are feeling unfair or dissatisfy usually generate negative e-WOM, telling his family and friends about those bad product or service as a compliant behavior (Blodgett, 1994). Moreover, researchers have demonstrated that online shopping websites provide consumers with platforms that enhance the way of communication between them in the form of electronic word of mouth (Cheung \& Lee, 2012; Majali \& Bohari, 2016) According to the literature, purchase intention is one of the most prominent and popular variables resulting from e-WOM (Lee \& Lee, 2009; Sher \& Lee, 2009). Customers recommendations are positively associated with intentions to purchase (Chang \& Chin, 2010). Customer reviews/comments and feedback are tremendously vital for online marketers, were found to have a positive influence on the customer's purchase intentions (Park, Lee, \& Han, 2007).

Moreover, most studies examining this relationship have conducted in the developed countries, and very limited has focused on the developing countries context. Thus the current study recommends examining this relationship in the context of a developing country like Jordan.

\section{Proposed Model}

Grounded on the pertinent literature review of the on TAM model, the proposed conceptual model in the current study developed in the context of online shopping by mapping the relationships between factors affecting online shopping and intention to shopping online. The model represents 
INTERNATIONAL JOURNAL OF ACADEMIC RESEARCH IN BUSINESS AND SOCIAL SCIENCES Vol. 8, No. 8, August 2018, E-ISSN: 2222-6990 @ 2018 HRMARS

an investigation mechanism in which these factors might potentially affect individuals' intention to shop online. Figure 1 shows the proposed model

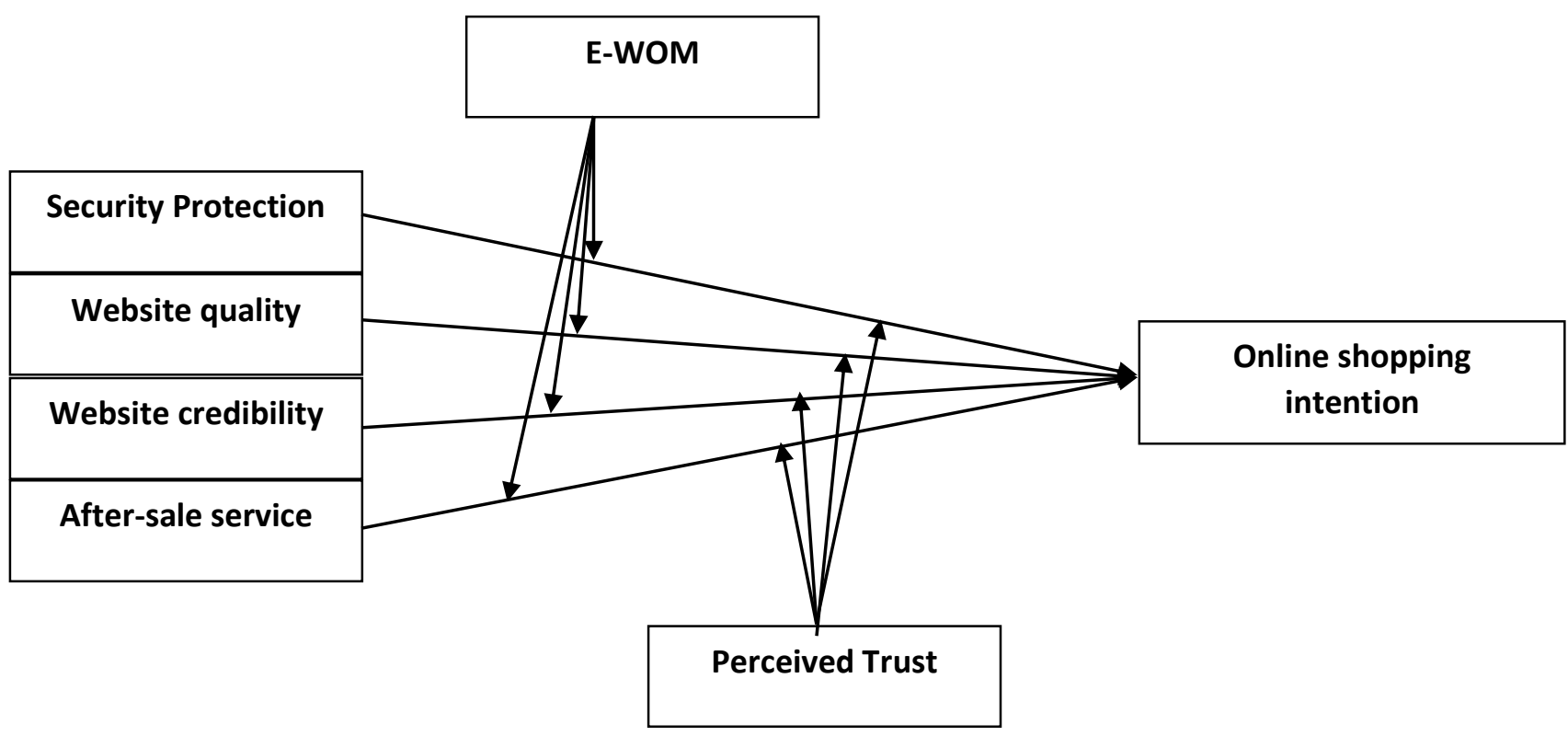

Figure 1: Conceptual Model

\section{Methodology}

The purpose of this paper is to propose a conceptual model signifying the impact of website credibility, website quality, security protection, after-sale service on online shopping intention, considering the moderating effect of perceived trust and e-WOM. The establish conceptual model recommends studying its implementation in the online shopping approach in Jordan. In order to establish the proposed model, the researchers have gone through the extensive review of relevant literature accessed from the numerous databases to ensure the reliability of the previous literature and to find the potential gaps in the past studies. Also, the TAM model literature supports the proposed conceptual model.

Furthermore, publications and news articles were somewhat less in this field to report the current situation of the online shopping level in Jordan, the use of a quantitative approach is a wellestablished approach. The quantitative approach allows the researcher to generalize the result to the whole population; present research uses simple random sampling. Based on the findings of Ndubisi and Sinti (2006) reported that respondents with higher income and better education like lecturers are more likely to use online shopping than other groups of customers. Therefore, the respondent of this study is Academic-staff in public universities in Jordan. Use two software package SPSS 20 and PLS version 2.0 M3 as statistical tools to facilitate data analysis. Numerous factors may lead to understanding the limitation of online shopping in Jordan. Therefore, the current study suggests studying the comprehensiveness of the proposed model could be improved by modeling more control variables affecting online shopping intention, such as review rating (Gauri, Bhatnagar, \& Rao, 2008). 
INTERNATIONAL JOURNAL OF ACADEMIC RESEARCH IN BUSINESS AND SOCIAL SCIENCES Vol. 8, No. 8, August 2018, E-ISSN: 2222-6990 @ 2018 HRMARS

\section{Discussion, Conclusion, and Implications}

Recalling again that the primary goal of the current study was to develop and propose the novel conceptual model indicating the impact of website credibility, website quality, security protection, after-sale service on online shopping intention. As discussed in the background, Jordan is facing numerous challenges in online shopping, and the department of statics in Jordan also highlighted that should enhance the level of online shopping in Jordan. Therefore, the current study considering these facts and recommends studying the proposed model. The proposed conceptual model will also provide the new insights for the future researches focusing either on online shopping in Jordan or any other developing countries.

Furthermore, in the pertinent literature of organizational performance, scholars have recommended that website credibility, website quality, security protection, and after-sale service factors affect the online shopping intention. Accordingly, the focus of this study is on a factor that affects the online shopping intention in Jordan. Also, this theoretical contribution would lead to the opening of new ideas for the other developing countries facing the same issues. Besides, the current study also contributes to the existing literature on the proposed constructs. The study has gone some way in order to enhance our understanding of online shopping intention. Moreover, suggesting to more extensive the scope of online shopping by studying it in the developing countries.

Despite theoretical contribution, the current study also provides the new insights for the online shopping retailer, and the future researchers to know the factors that drive Jordanian customers to shop online. The limited scope of this study was regarding the conceptual study. Therefore, it is recommended to study the proposed conceptual model empirically by the future researchers in the context of Jordan or any other developing country context.

\section{References}

Abbad, M., Abbad, R., \& Saleh, M. (2011). Limitations of e-commerce in developing countries: Jordan case. Education, Business and Society: Contemporary Middle Eastern Issues, 4(4), 280291.

Ahmed, D., \& Sanatullah, S. (2011). After Sales Service and Consumer Buying Behavior: An Empirical Investigation in Automobile Industry Of Pakistan. Market Forces, 7(3).

Al-dweeri, R. M., Obeidat, Z. M., Al-dwiry, M. A., Alshurideh, M. T., \& Alhorani, A. M. (2017). The Impact of E-Service Quality and E-Loyalty on Online Shopping: Moderating Effect of ESatisfaction and E-Trust. International Journal of Marketing Studies, 9(2), 92.

Al-Matarneh, N. S. (2016). Online Shopping Risks and Effect on Consumers Purchasing Behavior. International Journal of Online Marketing Research, 2(1), 62-69.

Al-Rawad, M. I., Al Khattab, A., Al-Shqairat, Z. I., Krishan, T. A., \& Jarrar, M. H. (2015). An Exploratory Investigation of Consumers' Perceptions of the Risks of Online Shopping in Jordan. International Journal of Marketing Studies, 7(1), 157-167.

Al-maghrabi, T., Dennis, C., \& Vaux Halliday, S. (2011). Antecedents of continuance intentions towards e-shopping: the case of Saudi Arabia. Journal of Enterprise Information Management, 24(1), 85-111.

Aladwani, A., \& Palvia, P. (2002). Developing and validating an instrument for measuring userperceived web quality. Information \& Management, 39(6), 467-476.

Aldhmour, F., \& Sarayrah, I. (2016). an Investigation of Factors Influencing Consumers ' Intention To Use Online Shopping : an Empirical Study in South of JORDAN. Journal of Internet Banking and Commerce, 21(2), 1-42. 
INTERNATIONAL JOURNAL OF ACADEMIC RESEARCH IN BUSINESS AND SOCIAL SCIENCES

Vol. 8, No. 8, August 2018, E-ISSN: 2222-6990 @ 2018 HRMARS

Alireza, F., Fatemeh, B., \& Pegah, M. (2011). How after-sales service quality dimensions affect customer satisfaction. African Journal of Business Management, 5(17), 7658-7664.

Altarifi, S., Al-hawary, S. I. S., \& Sakkal, M. E. E. Al. (2015). Determinants of E-Shopping and its Effect on Consumer Purchasing Decision in Jordan. International Journal of Business and Social Science, 6(1), 81-92.

Amini, A., Darani, M., \& Afshani, M. (2012). Effectiveness of marketing strategies and corporate image on brand equity as a sustainable competitive advantage. Interdisciplinary Journal of Contemporary Research in Business, 4(2), 192-205.

Anderson, E. W., \& Sullivan, M. W. (1993). The Antecedents and Consequences of Customer Satisfaction for Firms. Marketing Science, 12(2), 125-143.

Bai, B., Law, R., \& Wen, I. (2008). The impact of website quality on customer satisfaction and purchase intentions: Evidence from Chinese online visitors. International Journal of Hospitality Management, 27(3), 391-402.

Baron, R. M., \& Kenny, D. a. (1986). The Moderator-Mediator Variable Distinction in Social The Moderator-Mediator Variable Distinction in Social Psychological Research: Conceptual, Strategic, and Statistical Considerations. Journal of Personality and Social Psychology, 51(6), 1173-1182.

Belanger, F., Hiller, J. S., \& Smith, W. J. (2002). Trustworthiness in Electronic Commerce : The Role of Privacy, Security, and Site Attributes Trustworthiness in electronic commerce : the role of privacy, security, and site attributes. Elsevier, 11(July 2016), 245-270.

Blodgett, J. G. (1994). The Effects of Perceived Justice On Complainants' Repatronage Intentions ANd Negative Word Of Mouth Behavior. Journal of Consumer Satisfactio, Dissatisfaction and Complaining Behavior, 7(4), 1-14.

Chen, Hsu, I. C., \& Lin, C. C. (2010). Website attributes that increase consumer purchase intention: A conjoint analysis. Journal of Business Research, 63(9-10), 1007-1014.

Chen, M. Y., \& Teng, C. I. (2013). A comprehensive model of the effects of online store image on purchase intention in an e-commerce environment. Electronic Commerce Research, 13(1), 123.

Chen, P.-Y., Dhanasobhon, S., \& Smith, M. D. (2008). All Reviews are Not Created Equal: The Disaggregate Impact of Reviews and Reviewers at Amazon.Com. SSRN Electronic Journal. https://doi.org/10.2139/ssrn.918083

Chen, Y., \& Barnes, S. (2007). Initial trust and online buyer behaviour. Industrial Management \& Data Systems, 107(1), 21-36.

Chen, Y., Yan, X., Fan, W., \& Gordon, M. (2015). The joint moderating role of trust propensity and gender on consumers' online shopping behavior. Computers in Human Behavior, 43, 272-283.

Chevalier, J. A., \& Mayzlin, D. (2006). The Effect of Word of Mouth on Sales: Online Book Reviews. Journal of Marketing Research, 43(3), 345-354.

Corritore, C. L., Kracher, B., \& Wiedenbeck, S. (2003). On-line trust: Concepts, evolving themes, a model. International Journal of Human Computer Studies, 58(6), 737-758.

Cushman \& Wakefield. (2013). Global perspective on retail: online retailing. London.

David Gefen, E. K. and D. W. S. (2003). Trust and TAM in Online Shopping: An Integrated Model. Management Information Systems Research Center, University of Minnesota Is Collaborating with JSTOR to Digitize, Preserve and Extend Access to MIS Quarterly, 27(1), 51-90.

Debei, M. M. Al. (2014). The quality and acceptance of websites: an empirical investigation in the context of higher education. International Journal of Business Information Systems, 15(2), 170. 
INTERNATIONAL JOURNAL OF ACADEMIC RESEARCH IN BUSINESS AND SOCIAL SCIENCES

Vol. 8, No. 8, August 2018, E-ISSN: 2222-6990 @ 2018 HRMARS

DeLone, W. H., \& McLean, E. (2003). The DeLone and McLean Model of Information Systems Success. Journal of Management Information Systems, 19(9), 9-30.

Department of Statistics. (2017). Jordan in Figures. Amman.

Dodds, W. B., Monroe, K. B., \& Grewal, D. (1991). Effects of Price, Brand, and Store Information on Buyers' Product Evaluations. Journal of Marketing Research, 28(3), 307.

Doong, H. S., Wang, H. C., \& Foxall, G. R. (2011). An investigation of consumers' webstore shopping: A view of click-and-mortar company. International Journal of Information Management, 31(3), 210-216.

Everard, A., \& Galletta, D. F. (2005). How Presentation Flaws Affect Perceived Site Quality, Trust, and Intention to Purchase from an Online Store. Journal of Management Information Systems, 22(3), 56-95.

Flavián, C., Guinalíu, M., \& Torres, E. (2006). How bricks-and-mortar attributes affect online banking adoption. International Journal of Bank Marketing, 24(6), 406-423.

Ganguly, B., Dash, S. B., Cyr, D., \& Head, M. (2010). The effects of website design on purchase intention in online shopping: the mediating role of trust and the moderating role of culture. International Journal of Electronic Business, 8(4/5), 302.

Ganguly, S. B. D. (2009). Website characteristics, Trust and purchase intention in online stores: - An Empirical study in the Indian context. Journal of Information Science and Technology, 6(2).

Gauzente, C. (2004). Web Merchants' Privacy and Security Statements : How Reassuring Are They for Consumers ? a Two-Sided Approach. Journal of Electronic Commerce Research, 5(3), 181198.

George, J. F., Mirsadikov, A., \& Mennecke, B. E. (2016). Website Credibility Assessment: An Empirical - Investigation of Prominence-interpretation Theory. Transactions on HumanComputer Interaction, 8(2), 40-56.

Gotlieb, J. B., \& Sarel, D. (1992). The Influence of Type of Advertisement, Price, and Source Credibility on Perceived Quality. Journal of the Academy of Marketing Science, 20(3), 253-260.

Gregg, D. G., \& Walczak, S. (2010). The relationship between website quality, trust and price premiums at online auctions. Electronic Commerce Research, 10(1), 1-25.

Hasan, L., \& Morris, A. (2017). Usability Problem Areas on Key International and Key Arab Ecommerce Websites. Journal of Internet Commerce, 16(1), 80-103.

Hassan, L. M., Walsh, G., Shiu, E. M. K., Hastings, G., \& Harris, F. (2007). Modeling Persuasion in Social Advertising: A Study of Responsible Thinking in Antismoking Promotion in Eight Eastern EU (European Union) Member States. Journal of Advertising, 36(2), 15-31.

Hassanein, K., \& Head, M. (2007). Manipulating perceived social presence through the web interface and its impact on attitude towards online shopping. International Journal of Human Computer Studies, 65(8), 689-708.

Hennig-Thurau, T., \& Walsh, G. (2003). Electronic Word-of-Mouth: Motives for and Consequences of Reading Customer Articulations on the Internet. Journal of Electronic Commerce, 8(2), 5174.

Horrigan, J. B. (2008). The internet and consumer choice: Online Americans use different search and purchase strategies for different goods. Pew Internet \& American Life Project, 1-42.

Infosino, W. J. (1986). Forecasting New Product Sales from Likelihood of Purchase Ratings. Marketing Science, 5(4), 372-384.

Istizada. (2016). Jordan Online Marketing Country Profile | IstiZada. Retrieved July 27, 2018, from http://istizada.com/jordan-online-marketing-country-profile/ 
INTERNATIONAL JOURNAL OF ACADEMIC RESEARCH IN BUSINESS AND SOCIAL SCIENCES

Vol. 8, No. 8, August 2018, E-ISSN: 2222-6990 @ 2018 HRMARS

Johnson, T. J., \& Kaye, B. K. (2004). Wag the Blog: How Reliance on Traditional Media and the Internet Influence Credibility Perceptions of Weblogs Among Blog Users. Journalism \& Mass Communication Quarterly, 81(3), 622-642.

José-Cabezudo, R. S., \& Camarero-Izquierdo, C. (2012). Determinants of Opening-Forwarding E-Mail Messages. Journal of Advertising, 41(2), 97-112.

Khalil, H. (2017). The Role of the Quality of a Website in Consumer Perception. University of north Florida.

Kim, H. W., Xu, Y., \& Koh, J. (2004). A Comparison of Online Trust Building Factors between Potential Customers and Repeat Customers. Journal of the Association for Information Systems, 5(10), 392-420.

Kim, M.-J., Chung, N., \& Lee, C.-K. (2011). The effect of perceived trust on electronic commerce: Shopping online for tourism products and services in South Korea. Tourism Management, 32(2), 256-265.

Kim, M. (2015). Partisans and Controversial News Online: Comparing Perceptions of Bias and Credibility in News Content From Blogs and Mainstream Media. Mass Communication and Society, 18(1), 17-36.

Kumar, V. (2010). Customer Relationship Management. In Wiley International Encyclopedia of Marketing. Chichester, UK: John Wiley \& Sons, Ltd.

Lan Ho, T. H., \& Chen, Y. (2014). Vietnamese Consumers' Intention to Use Online Shopping: The Role of Trust. International Journal of Business and Management, 9(5).

Lee, J., Park, D., \& Han, I. (2011). The different effects of online consumer reviews on consumers' purchase intentions depending on trust in online shopping malls. Internet Research, 21(2), 187-206.

Lee, W., Chiu, Y., \& Liu, C. (2011). Assessing the effects of consumer involvement and service quality in a self-service setting. Human Factors and Ergonomics in Manufacturing \& Service Industries, 21(5), 504-515.

Lian, J. W., \& Lin, T. M. (2008). Effects of consumer characteristics on their acceptance of online shopping: Comparisons among different product types. Computers in Human Behavior, 24(1), 48-65.

Limbu, Y. B., Wolf, M., \& Lunsford, D. (2012). Perceived ethics of online retailers and consumer behavioral intentions. Journal of Research in Interactive Marketing, 6(2), 133-154.

Lin, C.-H., Chuang, S.-C., Kao, D. T., \& Kung, C.-Y. (2005). The role of emotions in the endowment effect. Journal of Economic Psychology, 27(4), 589-597.

Llach, J., Marimon, F., Alonso-Almeida, M. del M., \& Bernardo, M. (2013). Determinants of online booking loyalties for the purchasing of airline tickets. Tourism Management, 35, 23-31.

Loiacono, E. T., Watson, R. T., \& Goodhue, D. L. (2002). WebQual ${ }^{\mathrm{TM}}$ : A Measure of Web Site Quality. American Marketing Association, 432-438.

Lu, J., Tang, S., \& McCullough, G. (2000). An Assessment for Internet-Based Electronic Commerce Development in Businesses of New Zealand. Electronic Markets, 11(2), 107-115.

Lu, Y., Yang, S., Chau, P. Y. K., \& Cao, Y. (2011). Dynamics between the trust transfer process and intention to use mobile payment services: A cross-environment perspective. Information \& Management, 48(8), 393-403.

MacKenzie, S. B., \& Lutz, R. J. (1989). An Empirical Examination of the Structural Antecedents of Attitude toward the Ad in an Advertising Pretesting Context. Journal of Marketing, 53(2), 4865. 
INTERNATIONAL JOURNAL OF ACADEMIC RESEARCH IN BUSINESS AND SOCIAL SCIENCES

Vol. 8, No. 8, August 2018, E-ISSN: 2222-6990 @ 2018 HRMARS

Masoud, E. Y. (2013). The Effect of Perceived Risk on Online Shopping in Jordan. European Journal of Business and Management, 5(6), 76-88.

McCroskey, J. C. (1971). Ethos, credibility and communication in the real world. North Carolina Journal of Speech, 4(3), 24-31.

Mcknight, D. H., Cummings, L. L., \& Chervany, N. L. (2007). INITIAL TRUST FORMATION IN NEW ORGANIZATIONAL RELATIONSHIPS. Journals.Aom.Org, 23(3), 473-490.

Mohammad Ghazal. (2102). Fears of fraud still hinder e-commerce in Jordan - report - Jordan Vista. The Jordan Times.

Nabot, A., Garaj, V., \& Balachandran, W. (2014). Consumer Attitudes toward Online Shopping. International Journal of Social Ecology and Sustainable Development, 5(3), 13-24.

National E-commerce Strategy. (2016). Ministry of Information and Communications Technology.

Nuseir, M., \& Arora, N. (2010). Evidence of Online Shopping: A Consumer Perspective. International Review of Business Research Papers, 6(5), 90-106.

Ohanian, R. (1990). Construction and Validation of a Scale to Measure Celebrity Endorsers' Perceived Expertise, Trustworthiness, and Attractiveness. Journal of Advertising, 19(3), 39-52.

Oly Ndubisi, N., \& Sinti, Q. (2006). Consumer attitudes, system's characteristics and internet banking adoption in Malaysia. Management Research News, 29(1/2), 16-27.

Omar, K., Scheepers, H., \& Stockdale, R. (2011). eGovernment service quality assessed through the public value lens. Lecture Notes in Computer Science (Including Subseries Lecture Notes in Artificial Intelligence and Lecture Notes in Bioinformatics), 6846 LNCS, 431-440.

Pavlou, P. A., \& Gefen, D. (2004). Building effective online marketplaces with institution-basedtrust. Information Systems Research, 15(1), 667-675.

Ranganathan, C., \& Ganapathy, S. (2002). Key dimensions of business to consumer web sites'. Information and Management, 39(01), 457-465.

Richins, M. L. (1983). Negative Word-of-Mouth by Dissatisfied Consumers: A Pilot Study. Journal of Marketing, 47(1), 68.

Saeed, K. A., \& Abdinnour-Helm, S. (2008). Examining the effects of information system characteristics and perceived usefulness on post adoption usage of information systems. Information and Management, 45(6), 376-386.

Senecal, S., \& Nantel, J. (2004). The influence of online product recommendations on consumers' online choices. Journal of Retailing, 80(2), 159-169.

Sinha, \& Singh. (2015). Online shopping in india- An Indepth Analysis of perceived risks and Benefits. Vidyabharati International Interdiscplinary Research Journal, 4(2), 11-26.

Statistica-Corporation. (2015). Statistica-Corporation. Retrieved May 25, 2017, from http://statistica.io/resources/trial-download/

Strutton, D., Taylor, D. G., \& Thompson, K. (2011). Investigating generational differences in e-WOM behaviours. International Journal of Advertising, 30(4), 559-586.

Tha'er, A. M., \& Bohari, A. M. (2016). A Conceptual Model of Electronic Word of Mouth Communication through Social Network Sites: The Moderating Effect of Personality Traits. International Review of Management and Marketing, 6(7S), 265-269.

Thamizhvanan, A., \& Xavier, M. J. (2013). Determinants of customers' online purchase intention: an empirical study in India. Journal of Indian Business Research, 5(1), 17-32.

The Jordanian Telecommunications Regulatory Commission (TRC). (2013). Authorities block hundreds of websites in Jordan. 
INTERNATIONAL JOURNAL OF ACADEMIC RESEARCH IN BUSINESS AND SOCIAL SCIENCES

Vol. 8, No. 8, August 2018, E-ISSN: 2222-6990 @ 2018 HRMARS

Toufaily, E., Souiden, N., \& Ladhari, R. (2013). Consumer trust toward retail websites: Comparison between pure click and click-and-brick retailers. Journal of Retailing and Consumer Services, 20(6), 538-548.

Tsai, Y. C., \& Yeh, J. C. (2010). Perceived risk of information security and privacy in online shopping: A study of environmentally sustainable products. African Journal of Business Management, 4(18), 4057-4066.

Ubaid Ur Rahman, Muhammad Rizwan, Muhammad Rizwan, M. H. K. (2013). E-TAM Model: A Comprehensive Approach to Understand the Adoption of Electronic Shopping. Journal of Basic and Applied Scientific Research, 3(11), 178-188.

Vishwanath, A., \& Barnett, G. A. (2005). An Empirical Investigation into the Structure of Bidding in Online Auctions. Electronic Markets, 15(3), 261-268.

Wang, Y.-S., Lin, H.-H., \& Luarn, P. (2006). Predicting consumer intention to use mobile service. Information Systems Journal, 16(2), 157-179.

Wang, Y. D., \& Emurian, H. H. (2005). An overview of online trust: Concepts, elements, and implications. Computers in Human Behavior, 21(1), 105-125.

Wells, J. D., Parboteeah, D. V., \& Valacich, J. S. (2011). Online Impulse Buying : Understanding the Interplay between Consumer Impulsiveness and Website Quality. Journal of the Association for Information Systems, 12(1), 32-56.

White, C. J. (2010). The impact of emotions on service quality, satisfaction, and positive word-ofmouth intentions over time. Journal of Marketing Management, 26(5-6), 381-394.

$\mathrm{Wu}$, J., \& Chang, Y. (2005). Towards understanding members' interactivity, trust, and flow in online travel community. Industrial Management \& Data Systems, 10(5), 937-954.

Xu, Q. (2013). Social Recommendation, Source Credibility, and Recency. Journalism \& Mass Communication Quarterly, 90(4), 757-775.

Yaseen, H., Dingley, K., \& Adams, C. (2016). Capturing the Growth of E-Commerce in Jordan Using a Novel Research Approach, 3(2), 811-827.

Young Kim, E., \& Kim, Y. (2004). Predicting online purchase intentions for clothing products. European Journal of Marketing, 38(7), 883-897.

Zailani, S., Kheng, L. C., \& Fernando, Y. (2008). Service Quality Analysis On The Consumer Perceptions Toward Online Ticketing: Evidence In Malaysia. International Business Management.

Zakuan, N., Muniandy, S., Mat Saman, M. Z., Md Ariff, M. S., Sulaiman, S., \& Abd Jalil, R. (2012). Critical success factors of total quality management implementation in higher education institution: A review. International Journal of Academic Research in Business \& Social Sciences, 2(12), 19-32.

Zhang, X., \& Tang, Y. (2006). Customer perceived E-service quality in online shopping. Luleå University of Technology.

Zhou, T. (2013). An empirical examination of continuance intention of mobile payment services. Decision Support Systems, 54(2), 1085-1091. 